\title{
The impact of fiscal and monetary policy on economic growth and cyclical development of the economy
}

\author{
J. Lisý \\ University of Economics in Bratislava \\ 1 Dolnozemská cesta, Bratislava, 85235, Slovak Republic
}

\begin{abstract}
The existence of the cyclical development of the economy and searching for the effective fiscal and monetary policy as a tool to mitigate cyclical fluctuations will be for a long time a subject of many professional discussions. In particular, the crisis processes in the $21^{\text {st }}$ century meant a renewal of the debate between Keynesian and monetarist oriented economists. The aim of the article is to compare and evaluate different approaches to the effective application of fiscal and monetary policy instruments and the possibility of their practical application. Many economists have come to the conclusion that the implementation of monetary policy leads to the more effective allocation of production resources as in the case of fiscal expansion. It is obvious that even in the future there will be controversy about whether the cause of cyclical fluctuations is incorrectly implemented economic policy or the failure of economic and political institutions.
\end{abstract}

Keywords: cyclical development of the economy, fiscal expansion, monetary expansion

\section{Introduction}

The problems of economic growth, the existence of the cyclical development of the economy and searching for the effective fiscal and monetary policy as a tool to mitigate cyclical fluctuations will be for a long time a subject of many professional debates. Precrisis theoretical as well as economic and political consensus was a thesis that a stabilization of aggregate demand was the role of monetary policy, mainly in large economies. Setting up an appropriate system of taxes and subsidies, which would ensure an optimal growth of the potential output in terms of sustainable debt levels, is the task of fiscal policy. The 2008 global financial and economic crisis undermined this consensus as a reduction of interest rates close to zero significantly limited the effectiveness of the standard tools of economic policy in many developed countries.

\section{Literature review and methodology of the study}

The comparative analysis of different views on how to implement the fiscal and monetary expansion reveals that there are contradictions and different opinions among the various schools of the economic theory. The protagonists of these different approaches are the followers of the Keynesian economic theory on one side and the supporters of monetarism, a new classical macroeconomics and the Austrian school on the other side. 
Under specific conditions, the economic practice is using the recommendations of one or another group of economists to a varying extent.

In the economic literature, there are still many theoretical justifications for the cyclical development of the economy. They can be divided into the real theories of business cycle in which the cyclical fluctuations are caused by the real forces such as innovation and investment waves. It may occur as investment pessimism or investment optimism. This causes the fluctuations in aggregate demand. According to some economists (i.e. J.M. Keynes, 1963), the fluctuations in aggregate demand require to apply the fiscal instruments of regulation. In the case of a decline in total effective demand they propose to apply fiscal expansion. The consequences and effects of fiscal expansion are assessed differently by individual economic schools. On the basis of the Keynesian theoretical postulates, Neo-Keynesians justify that the cyclical development of the economy is a proof of not functioning the market mechanism which requires the active government intervention (Blanchard, 2012; Krugman, 2009; Mankiw, 1999).

The monetary theories of the business cycle assume that the cyclical fluctuations are caused by the changes in the money supply (Friedman, 1993; Hayek, 1975; Mises, 1998). The authors and followers of these theories are mainly the representatives of the classical economics (A. Smith, J.B. Say), the Austrian school (F.A. Hayek, L. Mises, M.N. Rothbard), the representatives of monetarism (M. Friedman, K. Brunner, J. Jordan) and the theory of rational expectations (R.E. Lucas).

Mentioned theories of the business cycle are not mutually exclusive because the real factors as well as monetary factors may also be the cause of cyclical developments. This is all about what individual economists emphasize more, respectively what they consider to be a primary or secondary factor. It also follows from the approach of different authors to the economy and the functioning of the market mechanism. The followers of classical economics are looking at the problem in terms of aggregate supply and the followers of Keynesian economics emphasize the approach of the aggregate demand.

\section{The impossibility of a crisis arising according to classical economics}

The classical economics assumes that the market system is inherently stable and functioning of the market mechanism automatically raises the macroeconomic equilibrium. Therefore the economic crisis cannot arise. The economy is functioning at the level of potential output and full employment. In the classical model, the macroeconomic equilibrium is achieved at the level of potential output. Aggregate supply does not respond to the changes in aggregate demand while changes in aggregate demand cause changes in the price level but do not affect the level of output.

The aggregate demand may increase due to fiscal and monetary policy. Meantime, the aggregate demand exceeds aggregate supply. Enterprises, however, cannot produce or offer more products because they have no additional labour force to employ and thus increase supply. Therefore, the price level rises. A price increase reduces the real money supply which causes the increase in the interest rates and the consequent decline in private spending on one side and release the space for the growth of government spending on the other. As a result, an autonomous private investment and private consumer spending 
are crowded out. Their total volume is equal to the volume of increased government spending. This creates a balance with a greater volume of government spending and a smaller volume of private autonomous spending but at a higher price level.

Crowding out effect, as a result of fiscal expansion, arises on the supply side. In the classical model, fiscal expansion changes the structure of demand and production. It increases the amount of government spending and reduces the value and amount of private autonomous expenditure. The price level increases but the total amount of output and employment does not change.

Expansionary monetary policy increases the money supply and it leads to the growth of aggregate demand. At the initial level $P_{0}$, the aggregate demand exceeds aggregate supply that companies could not meet because aggregate supply could not increase in the classical economics. This leads to an increase in the price level and the macroeconomic equilibrium is achieved at the higher price level. In the classical economics, monetary expansion causes that the price level increases to the same extent as the nominal amount of money. Total output and employment do not change and they are at the level of potential output and full employment. From the above characteristics it follows that the monetary expansion has no impact on the real economic variables in the classical model. Only the price level varies proportionally with the growth of money supply. Such a phenomenon is characterized by so-called neutrality of money which means that the changes in the nominal money supply affect the price level, but have no impact on the real economic variables.

The representatives of the Austrian school see the cause of the price increases in the fact that the source of this expansion is not in the voluntary savings but in so-called forced savings. Monetary expansion, which is not based on voluntary (real) savings, causes bad investment and leads to the spontaneous beginning of recession.

"We have to search for a cause of the recession in the absence of voluntary savings that are necessary for the reconstruction of the production structure which turns out to be too capital intensive. The recessions have their root in the credit expansion of the banking system which is not accompanied by a corresponding behaviour of economic agents. These entities do not try to increase their voluntary savings" (Soto, 2009).

Jesús Huerta de Soto, a follower of the Austrian School of Economics, assesses the implications of the monetary credit expansion. He points out that since the beginning of the $21^{\text {st }}$ century the cyclical development was due to the artificial credit expansion of the Federal Reserve, unsupported by an increase in voluntary household saving. Newlycreated loans (of money households have not first saved) provided by the banks to the entrepreneurs were used for the major construction and development projects. It led to a financial bubble, which negatively affected the real economy in the form of economic recession. A crisis in a mortgage system and a failure of many banks occurred in a situation where the value of their liabilities exceeded the value of assets in the form of mortgages granted.

From the knowledge of the neutrality of money the classical economists draw the conclusion that in the economy operates an automatic mechanism which directs the economy to full employment and ensures that the real product will not deviate significantly from the level of potential output in the long term. From the classical concept of economics (the Austrian school) implies, that there never incur losses in the economy resulting from 
unused production resources because the economy is at the level of potential output. This means that all production capacity is efficiently used and there is full employment. This also implies that the monetary expansion, the aim of which is to affect the aggregate demand, is ineffective because it does not have an impact on total volume of output and cannot affect the rate of employment. It causes only a rise in the price level and crowding out private investment by government investment, leading to inefficiency of the economy.

It seems that these assumptions do not correspond to the real economic conditions. In real economic life, the prices and wages are not perfectly flexible. Therefore neither the labour market is "self regulating" and there exists involuntary unemployment. There is no perfect information of market agents on the prices and wages. The performance of the economy fluctuates and therefore the real GDP does not correspond to the potential product. J. M. Keynes responded to these issues in the $20^{\text {th }}$ century.

\section{Cyclical fluctuations according to Keynesian economics}

According to J.M. Keynes (Keynes, 1963), a primary cause of the recession is the lack of effective demand. He proposes to implement the active state regulation and expansionary fiscal policy at a time when resources are not fully used. If the government implements expansionary fiscal policy, it increases government spending and thus aggregate demand. A situation, in which aggregate demand exceeds aggregate supply, causes a pressure to increase the output and at the same time the price level. It is obvious that fiscal expansion leads to the increase in output and the price level at the same time but nominal wages have failed to adapt to a new economic situation in the short term and remained at the original level, reducing real wages. Simultaneously, the growing demand for capital goods raises demand for the loans, thus increasing the interest rate.

Due to the expansionary monetary policy, aggregate demand exceeds aggregate supply which causes the pressure to increase the output, production, employment as well as the price level. It follows that due to the monetary expansion the increase in output occurs in the short run as well as the increase in the price level. In the short term, nominal wages are fixed and therefore due to the increase in the price level, real wages decline. As the central bank increases the money supply, the interest rates are declining.

In this situation, the real wage compared to its initial state decreased. As soon as the employees register a decline in real wages, the trade unions will require an increase in nominal wages in the next collective agreements in proportion with the increase in the price level. In the long term, the nominal wages will rise which leads to increases in the costs of companies and causes a consequent reduction in the amount of produced goods and services at any price level.

According to the following conditions, we can define these long-term effects of monetary expansion:

- the total output is identical in the long-run and the current product is at the level of potential output;

- the employment is at the natural rate of unemployment;

- the real wage will not change as a result of the proportional nominal wage growth and price stability;

- the price level rises proportionally with the increase in the money supply. 
From the above characteristics it follows that the long-term effects of fiscal and monetary expansion are the same as the effects of fiscal and monetary expansion in the classical theory. Using instruments of fiscal and monetary policy, the government could implement so-called stabilizing economic policy aimed at achieving full and efficient use of production resources.

On the basis of the Keynesian theoretical postulates, Neo-Keynesians justify that the cyclical development of the economy is a proof of not functioning the market mechanism which requires the active government intervention (Blanchard, 2012; Krugman, 2009; Mankiw, 1999). The theories of Neo-Keynesian economists are also focused on the demand-cycle theories, arguing that monetary policy affects production and employment in the short run.

The challenging theoretical and practical economic inspirations are the views of P. Krugman (2009) who responds to the events in the world economy after 2008. He was influenced by Keynes's views. Krugman points out, why the performance of the economy is declining and unemployment rising. He states that simply because all of us - the consumers, businesses and government spend too little. By decreasing sales of goods it makes no sense to increase the production which in turn leads to the unemployment. We all suffer from a critical lack of demand. People are buying fewer goods than they are able to produce and also spend less than they earn. Krugman urges that even the monetary instruments have failed to solve these problems. Fed's monetary base has tripled since 2008, but the economic performance has not increased. And even if the interest rate is around zero, the total demand is still insufficient. The world requires governments to increase their spending (even military) and thus get the country out of depression. The fiscal expansion would accelerate the growth of interest rates which ensure the escape from a liquidity trap (Soto, 2009; Šikula, 2009; Švihlíková, 2010; Čaplánová and Šujanský, 2011; Arrow, 2012; Lisý, 2011; Dujava, 2016).

\section{Cyclical fluctuations according to monetarists and the Austrian school}

Monetarists and the representatives of the Austrian school have criticized the Keynesian economic theory. The basis of monetarist theory of the business cycle is stable demand for money because according to Friedman it does not depend on conjectural fluctuations. Based on this assumption monetarists see the cause of output and employment fluctuations in a supply that is affected by the central bank.

At first sight it might seem that the Austrian and Monetarist business cycle theories are similar. In fact, they are diametrically different. Monetarists assume that on the basis of the equation of exchange, according to the quantity theory of money, they are able to explain all macroeconomic problems, including the cyclical development of the economy. According to the Austrian School, monetarists are unable to explain the causes of the recession and to submit any valid theoretical arguments. Monetarists recommend applying such an economic policy that treats only the symptoms but not the real causes of the crisis.

Monetarists have no satisfactory theory of the business cycle and believe that the crisis and depression are caused by the "monetary contraction". This is a naive and superficial 
diagnosis confusing cause and effect. The economic crises arise because the credit expansion and inflation distort the production structure firstly, which later appears as a crisis, monetary contraction and recession (Soto, 2009). This includes a criticism and rejection of monetarist theory of the business cycle. F.A. Hayek notes that a main shortcoming of monetarist business cycle theory is that it pays attention only to the impacts of the changes in the quantity of money on the general price level and not on the structure of relative prices. The consequence is it ignores the allocation of resources which is a cause of unemployment.

Even today, many economists try to identify the causes of differences in the performance of the economies of individual countries. Based on the works of Acemoglu (2009) and Weil (2009), we can mention the four most important: the geographic hypothesis, the cultural hypothesis, the lack of knowledge hypothesis and the institutional hypothesis.

The questionable instrument of monetary regulating could be a quantitative easing $(\mathrm{QE})$ of the European Central Bank. The aim of this measure is to prevent a deflationary spiral, increase inflationary rise in prices close to 2 percent, increase the flow of investment, enhance exports and thus boost the economic growth in the Eurozone countries. It seems, on the basis of measures taken, the ECB assumes monetary expansion contributes to more efficient allocation of production resources such as the fiscal policy.

\section{Results}

The comparative analysis of different views on how to implement the fiscal and monetary expansion reveals that there are contradictions and different opinions among the various schools of the economic theory. Analysis of the causes and searching for the solutions on how to prevent such a crisis that we have witnessed in the first decade of the $21^{\text {st }}$ century is still the subject of many discussions, the timing and the content of which depends on their theoretical and methodological economic orientation. The liberalminded economists will always claim that excessive regulation is the cause of every crisis. On the contrary, the followers of Keynesianism will argue that the cause of the crisis is the lack of regulation. A special feature of the 2008 crisis was that the fiscal and monetary policies were both dysfunctional and ineffective. Neither of the solutions which were available to economic policy makers could be effectively used.

\section{Conclusion}

Everyone will probably agree that it is the range and quality of regulation and the related moral hazard in the context of accepting accumulation of credit expansion of governments as well as the population that will be a central theme of further discussions. It is obvious that even in the future there will be controversial debates about whether the cause of cyclical fluctuations is incorrectly implemented economic policy or the failure of economic and political institutions.

(C) Lisý J., 2018

This work is licensed under a Creative Commons Attribution 4.0 International License 


\section{References}

Arrow K. J. (2012). Economic Theory and the Financial Crisis. Information System Frontiers, 14(5), 967-970.

Acemoglu D. (2009). Introduction to Modern Economic Growth. Oxford, Princeton University Press.

Blanchard D. et al. (2012). In the Wake of the Crisis: Leading Economists Reassess Economic Policy. Cambridge, The MIT Press.

Čaplánová A., Šujanský M. (2011). Teoretické prístupy k ekonomickému cyklu - východisko pre pochopenie súčasných krízových procesov. Ekonomické rozhl'ady, 40(1), 22-38.

Dujava D. (2016). Ekonomické krízy a ekonomická veda. Bratislava, Wolters Kluwer.

Friedman M. (1993). Kapitalismus a svoboda. Praha, Liberální institut.

Hayek F. A. (1975). Monetary Theory and the Trade Cycle. New York, Augustus M. Kelley Publishers.

Keynes J. M. (1963). Obecná teorie zaměstnanosti, úroku a peněz. Praha, Nakladatelství Československé akademie věd.

Krugman P. (2009). The Return of Depression Economics and the Crisis of 2008. New York, W.W. Norton \& Company.

Lisý J. a kol. (2011). Ekonomický rast a ekonomický cyklus. Teoretické a praktické problémy. Bratislava, Iura Edition.

Mankiw N. G. (1999). Zásady ekonómie. Praha, Grada Publishing.

Mises L. (1998). Liberalismus. Praha, Liberální institut.

Sojka M. (1999). John Maynard Keynesa a současná ekonomie. Praha, Grada Publishing.

Soto J. H. (2009). Penize, banky a hospodářské krize. Praha, ASPI, Liberální institut.

Šikula M. (2009). Kritická miera rozporov civilizácie a globálna ekonomické kríza. Ekonomický časopis, $57(8), 732-755$.

Švihlíková I. (2010). Globalizace a krize: souvislosti a scénáře. Všeň, Grimmus.

Weil D. (2009). Economic Growth. Boston, Pearson Addison Wesley.

\section{Acknowledgements:}

The paper was prepared within the frame of the research project VEGA No. 1/0246/16 entitled "Efficiency of fiscal and monetary policy during the economic cycle".

\section{Article history:}

Received: 02 July 2018

Revised: 15 August 2018

Accepted: 16 September 2018

\section{For citation:}

Lisý J. (2018). The impact of fiscal and monetary policy on economic growth and cyclical development of the economy. RUDN Journal of Economics, 26(3), 439-446. DOI: 10.22363/23132329-2018-26-3-439-446

\section{Bio note:}

Lisý Ján, Professor at the University of Economics in Bratislava, Faculty of National Economy, Department of Economic Theory. Contact information: e-mail: jan.lisy@euba.sk 


\title{
Влияние фискальной и денежно-кредитной политики на экономический рост и циклическое развитие экономики
}

\author{
Я. Лизи \\ Экономический университет в Братиславе \\ Словацкая Республика, 85235, Братислава, Долноземска цеста, 1
}

Цикличность развития экономики и поиск эффективной фискальной и денежно-кредитной политики как инструмента смягчения циклических колебаний будут долгое время оставаться предметом многих профессиональных дискуссий. В частности, кризисные процессы в XXI в. возобновили дебаты между кейнсианцами и сторонниками политики монетаризма. Цель статьи - сравнить и оценить различные подходы к эффективному применению инструментов финансовой и денежно-кредитной политик и возможности их практического применения. Многие экономисты пришли к выводу, что осуществление денежно-кредитной политики ведет к более эффективному распределению производственных ресурсов, как в случае фискальной экспансии. Очевидно, что даже в будущем продолжатся споры о том, является ли причиной циклических колебаний неправильная реализация экономической политики или провал экономических и политических институтов.

Ключевые слова: циклическое развитие экономики, фискальная экспансия, монетарная экспансия

\section{История статьи:}

Дата поступления в редакцию: 2 июля 2018

Дата проверки: 15 августа 2018

Дата принятия к печати: 16 сентября 2018

\section{Для цитирования:}

Лизи Я. Влияние фискальной и денежно-кредитной политики на экономический рост и циклическое развитие экономики // Вестник Российского университета дружбы народов. Серия: Экономика. 2018. T. 26. № 3. C. 439-446. DOI: 10.22363/2313-2329-2018-26-3-439446

\section{Сведения об авторе:}

Лизи Ян, профессор Экономического университета в Братиславе, факультет народного хозяйства, кафедра экономической теории. Контактная информация: e-mail: jan.lisy@euba.sk 